\title{
SOME MEDUSAE FROM NEW CALEDONIA
}

$\operatorname{AUTHOR}(S)$ :

Uchida, Tohru

CITATION:

Uchida, Tohru. SOME MEDUSAE FROM NEW CALEDONIA.

PUBLICATIONS OF THE SETO MARINE BIOLOGICAL LABORATORY 1964, 12(1): 109-112

\section{ISSUE DATE:}

1964-06-30

URL:

http://hdl.handle.net/2433/175348

RIGHT: 


\title{
SOME MEDUSAE FROM NEW CALEDONIA ${ }^{1 / 2)}$
}

\author{
TOHRU UCHIDA \\ Zoological Laboratory, Faculty of Science \\ Hokkaido University, Sapporo
}

With 3 Text-figures

Recently Dr. Tokioka of the Seto Marine Biological Laboratory intrusted to the writer some medusan specimens obtained by the Melanesian Expedition carried out under the auspices of the Ôsaka Museum of Natural History in 1958. These specimens were all collected from the following localities of New Caledonia.

Noumea Port, 0-10 m, Nov. 14, 1958.

In a lagoon south-east to Noumea, surface, Nov. 6, 1958.

The medusae contained in this collection will be described as follows and the type specimens will be deposited in the Natural History Museum above mentioned.

\section{Laodicea undulata (FORBES et GOODSIR)}

(Fig. 1)

Six specimens probably referable to this cosmopolitan species were examined. The largest specimen among them is $6.2 \mathrm{~mm}$ in diameter and flatter than a hemisphere. Stomach, short and quadratic, with four crenulated lips. Gonads developed upon the radial canals, connected with the stomach, undulating several times. Tentacles solid, 80 in number, each with a basal bulb faintly developed. Tentacle bulbs each furnished with a distinct abaxial endodermal spur. No abaxial ocellus could be seen. Club-shaped cordyli present, usually one between successive tentacles. No spiral cirri could be observed. KRAMP (1919) reports that in some specimens the cirri were often entirely absent. The cirri are possibly liable to be shed off in preservation. A few smaller specimens in this collection were observed to retain a few cirri.

1) Scientific Results of the Melanesia Expedition, No. 17 and Contributions from the Ôsaka Museum of Natural History, No. 89.

2) Contributions from the Akkeshi Marine Biological Station, No. 124.

Publ. Seto Mar. Biol. Lab., XII (1), 1964. (Article 5) 


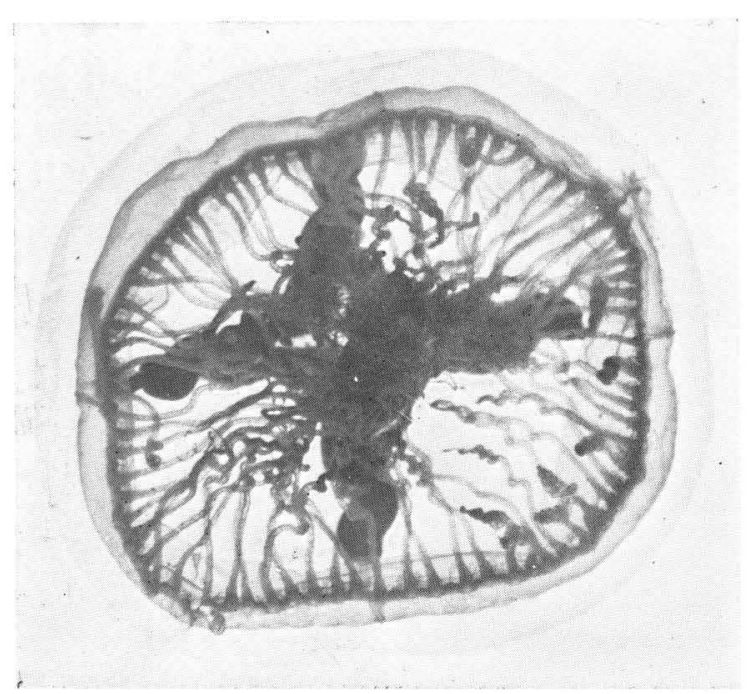

Fig. 1. Laodicea undulata (Forbes \& Goodsir); oral view, $\times$ about 12 .

\section{Irene hexamalis (GoETTE)}

Five specimens of this warm-water species, including a specimen with seven radial canals.

\section{Phialidium sp.}

On account of ill-preservation the specific identification could not be given.

\section{Eutima neucaledonia n. sp.}

(Figs. 2, 3)

Two specimens were examined. The smaller specimen is flat-dome-like, with thin gelatinous substance, $4.5 \mathrm{~mm}$ in diameter; peduncle with manubrium, $3.5 \mathrm{~mm}$ in length. Tentacles eight in number, four in perradii and four in interradii. Perradial tentacles are well-developed, each with an enlarged base and a long extensile shaft which reaches nearly the diameter in preserved condition. Interradial tentacles not so well developed, but each provided with a lateral cirrus on each side. Between the perradial and interradial tentacles are found three tentacle-warts and a closed statocyst in each quadrant. These tentacle-warts are equipped with a pair of cirri at their base. Velum well-developed. Four radial canals narrow, stout and connected with the ring canal. One of the radial canals is bifurcated near the summit. The peduncle of the manubrium is long, nearly attaining to the length of bell-diameter. Stomach short and with four 
slightly crenulated lips. Gonads appear as narrow linear bodies in the middle portion of the radial canals.

The larger specimen, very flat and $9 \mathrm{~mm}$ in diameter, the opening of umbrella being about $7 \mathrm{~mm}$ in diameter. Eight tentacles; four perradial and four interradial, all well-developed, extensile, nearly attaining to the bell-diameter in length but all without cirri. Between the perradial and interradial tentacles are found six or seven small tentacle warts and a statocyst which is situated nearer to

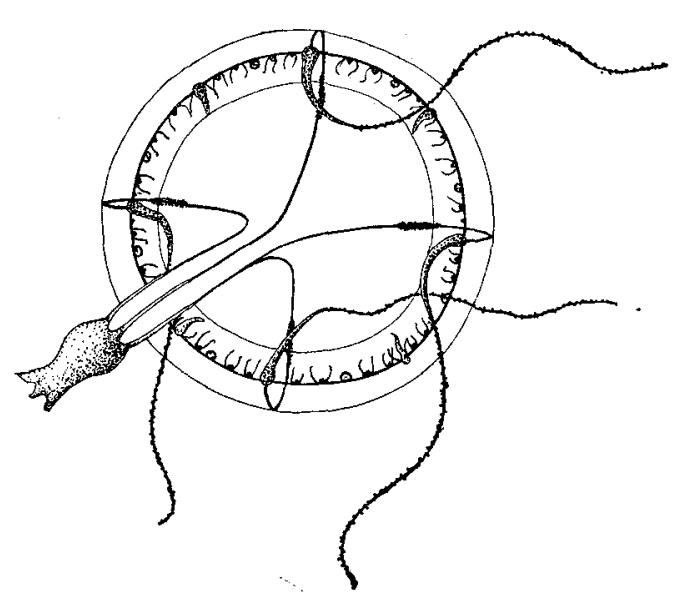

Fig. 2. Eutima neucaledonia n. sp., $4.5 \mathrm{~mm}$ in diameter.

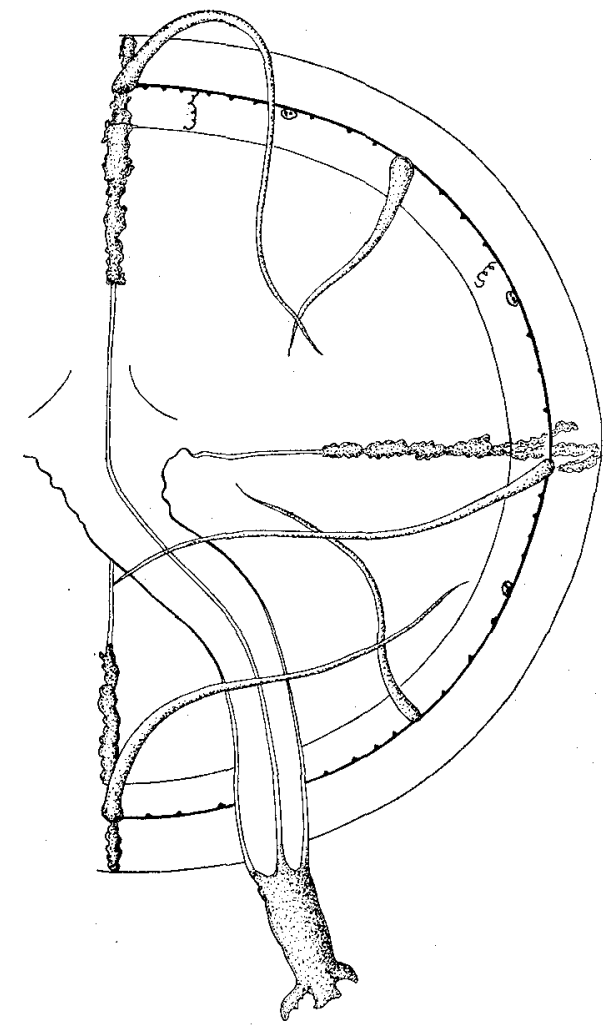

Fig. 3. Eutima neucaledonia n. sp. showing two quadrants and manubrium, $9 \mathrm{~mm}$ in diameter.

the perradius. In some tentacle-warts lateral cirri are seen, but in most of them they are wanting. Velum well-developed. Four radial canals narrow, stout and connected with the radial canal. Two of these canals are branched near the summit. The peduncle of the manubrium is long, nearly reaching the belldiameter. Stomach short and with four crenulated lips. Gonads linear, with many lateral swellings, developed only on the radial canals, from near the bell margin upwards, leaving upper portion of radial canals free. Two gonads are 
extending to the side branches of the radial canals.

Remarks. VANNUCCI (1957) describing Eutima mira gave a good review on all species hitherto reported. In her paper she pointed out that the number of gonads must be considered as the decisive differential character, there being only four, on peduncle, in gracilis and eight, four on subumbrella and four on peduncle, in mira. According to her key E. japonica is only species with eight tentacles and four subumbrellar gonads alone. The new species here described agrees with $E$. japonica in these points and differs from other species of the genus. But the two species are quite different in the length of peduncle and shape of gonads. Moreover, in the adult specimen of the new species cirri at the base of the tentacles are lacking, though they may be probable to be shed off in preservative.

\section{Aglantha digitale (O. F. MÜLLER)}

A small specimen was found in the collection.

Aurelia sp. (juv.)

A young medusa has four perradial and four interradial canals which give rise to only a pair of side branches which are almost symmetrically disposed of.

\section{REFERENCES}

Kramp, P. L. 1919. Medusae, part 1. Leptomedusae. Dan. Ingolf-Exped., Vol. 5, Pt. 8, pp. 1111, pls. 1-5.

1961. Synopsis of the medusae of the world. Jour. Mar. Biol. Ass. United Kingdom, Vol. 40, pp. 5-469.

RAnson, M. G. 1933. Revision de la collection des méduses du Muséum National d'Histoire Naturelle (suite 1). Bull. Mus. 2e Sér., Tome 5, pp. 223-229.

1934. The same. Tome 6, pp. 68-77.

VANNUCCI, M. 1957. On Brazilian Hydromedusae and their distribution in relation to different water masses. Bol. d. Instituto Oceanografico, Tomo 8, Fasc. 1 e 2, pp. 20-109. 